\title{
Bioedusiana
}

Blổogy

Education

Department

http://jurnal.unsil.ac.id/index.php/bioed

DOI: https://doi.org/10.37058/bioed.v5i2.2005

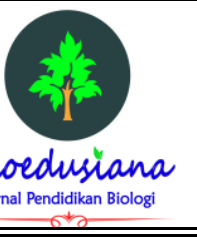

\section{Belajar Virus dengan Komik: Pengaruhnya terhadap Motivasi dan Hasil Belajar (Studi Eksperimen di Kelas X MAN Tasikmalaya Tahun Ajaran 2019/2020)}

\section{Learning Viruses with Comics: Their Effect on Motivation and Learning Outcomes (Experimental Study in Class X MAN Tasikmalaya Academic Year 2019/2020)}

\author{
Inkaa Setya Wulan $^{1}$, Purwati Kuswarini Suprapto ${ }^{2 *}$, Popo Musthofa Kamil ${ }^{3}$ \\ 1,2,3 Jurusan Pendidikan Biologi Universitas Siliwangi, J1. Siliwangi No. 24, Tasikmalaya, 46115
}

\begin{abstract}
Abstrak
Motivasi dan hasil belajar pada hakikatnya dapat ditingkatkan dengan berbagai cara, salah satunya dengan pemberian media pembelajaran yang menarik berupa komik. Media komik merupakan bentuk komunikasi visual yang mudah untuk dipahami karena menyajikan serangkaian gambar dan membentuk alur cerita yang memuat suatu informasi. Penelitian ini bertujuan untuk mengetahui pengaruh media komik terhadap motivasi dan hasil belajar pada materi virus di kelas X MAN Kabupaten Tasikmalaya. Penelitian ini dilaksanakan pada bulan November 2019 sampai dengan bulan Januari 2020 di MAN Kabupaten Tasikmalaya. Metode yang digunakan dalam penelitian ini adalah true experiment. Populasi dalam penelitian ini adalah seluruh peserta didik kelas X MIA MAN Kabupaten Tasikmalaya. Sampel penelitian diambil dengan teknik cluster random sampling, sehingga diambil sebanyak 2 kelas, yaitu kelas X MIA 5 yang proses pembelajaran menggunakan media pembelajaran komik, dan X MIA 7. Sampel penelitian diambil dengan teknik cluster random sampling. Instrumen yang digunakan dalam penelitian ini adalah tes hasil belajar pada materi virus dan angket motivasi belajar. Hasil belajar diukur dengan menggunakan tes soal pilihan majemuk sebanyak 35 nomor, dan pengukuran motivasi belajar dilakukan dengan menggunakan angket yang berupa skala sikap sebanyak 22 nomor. Teknik analisis data yang digunakan adalah U Mann Whitney . Berdasarkan hasil penelitian, diperoleh simpulan bahwa ada pengaruh positif media komik terhadap motivasi dan hasil belajar peserta didik pada materi virus di kelas X MAN Kabupaten Tasikmalaya.
\end{abstract}

Kata kunci: Media Pembelajaran; Komik; Motivasi; Hasil Belajar

\begin{abstract}
In essence, motivation and learning outcomes can be improved in various ways, one of which is by providing interesting learning media in the form of comics. Comic media is a form of visual communication that is easy to understand because it presents a series of pictures and forms a story line that contains information. This research aims to determine the effect of comic learning to motivation and result of learning. This research was conducted in September 2019 until January 2020 at Xth grade Islamic Senior High School at Tasikmalaya Regency. The method that used in this research was true experiment. The population in this research was all Xth grade of Math and Science classes of Islamic senior high school at Tasikmalaya Regency. The research sample was taken using cluster random sampling technique, so that 2 classes were taken is Xth grade of Math and Science class 5 studying with comic learning media and Xth grade of Math and Science class 7 as control. The samples taken by cluster random sampling technique. The instruments used in this research are a learning result test in virus lesson and a learning motivation questionnaire. Learning result were measured using 35 number compound choice test questions, and learning motivation measurements were carried out using a questionnaire in the form of skala sikap of 22 numbers. The data analysis technique used is U Mann Whitney. Based on the results of the study, it was concluded that there is an influence of comic media on students' motivation and learning result on virus lesson in Xth grade Islamic Senior High School at Tasikmalaya Regency.
\end{abstract}

Keywords: Comic Learning Media; Learning Motivation; Learning Result

\section{Article History}

Received: August, 20 ${ }^{\text {th }}$ 2020; Accepted: December, 28 ${ }^{\text {th }}$ 2020; Published: December, $31^{\text {st }} 2020$

Corresponding Author*

Purwati Kuswarini Suprapto, Jurusan Pendidikan Biologi FKIP Universitas Siliwangi, E-mail: purwatik1@gmail.com 


\section{PENDAHULUAN}

Pendidikan merupakan suatu komponen yang sangat penting untuk dimiliki oleh setiap individu. Dengan pendidikan, ilmu yang berupa nilai-nilai pengetahuan terus ditransfer kepada setiap individu dari generasi ke generasi, demi menciptakan masyarakat yang siap menghadapi perubahan zaman dan siap menciptakan masa depan kehidupan bangsa dan negara yang lebih baik (Nurkholis, 2013). Proses pembelajaran merupakan salah satu aktivitas yang sangat mempengaruhi apakah pendidikan dapat diperoleh peserta didik dengan baik atau tidak. Pembelajaran tercipta karena adanya proses interaksi yang bersifat edukatif antara guru dan peserta didik, dimana guru berperan sebagai fasilitator dan peserta didik sebagai subjek yang menerima ilmu (Emda, 2017). Untuk menempuh usaha dalam mencapai tujuan pembelajaran, diperlukan komponen-komponen untuk menciptakan suasana belajar dan pembelajaran yang mendukung. Dalam hal tersebut, guru memiliki kewajiban mempersiapkan berbagai komponen yang diperlukan supaya peserta didik mampu belajar dengan baik.

Namun, kecenderungan yang sering terjadi adalah pembelajaran tidak begitu terlihat menarik bagi peserta didik. Seperti yang dinyatakan oleh Cimer (2012) dalam Raida (2018), materi-materi biologi cenderung dipandang sulit dipelajari oleh peserta didik karena beberapa alasan, salah satunya adalah karena banyaknya objek dari biologi yang tidak dapat diamati secara langsung dan bersifat abstrak. Hal ini menyebabkan peserta didik merasa kesulitan untuk memahami materi yang diajarkan. Tidak hanya pada peserta didik, terkadang guru pun cukup mengalami kesulitan untuk memvisualisasikan materi yang bersifat cukup abstrak agar dapat mudah dipahami peserta didik.

Berdasarkan hasil observasi dan wawancara kepada guru MAN Kabupaten Tasikmalaya yang dilaksanakan pada tanggal 12 Juli 2019, sebagian besar peserta didik kurang termotivasi untuk mempelajari materi biologi. Kurang bervariatifnya media belajar yang difasilitasi sekolah, diduga menjadi salah satu faktor yang membuat peserta didik merasa jenuh untuk melaksanakan kegiatan belajar. Selain itu, karena MAN Kabupaten Tasikmalaya merupakan sekolah yang berbasis islam, penekanan sekolah kepada peserta didik dalam menuntut ilmu pengetahuan islam cukup tinggi bila dibandingkan sekolah umum lainnya. Karena jumlah mata pelajaran yang harus dikuasai oleh peserta didik MAN Kabupaten Tasikmalaya lebih banyak daripada sekolah umum lainnya yaitu berjumlah 18 mata pelajaran dengan 5 mata pelajaran tambahan daripada sekolah pada umumnya, diduga menjadi salah satu faktor kesulitan bagi para peserta didik untuk mencapai capaian pembelajaran. Kesulitan peserta didik dalam mencapai capaian pembelajaran mengindikasikan kurangnya kemampuan peserta didik dalam memahami materi pembelajaran, sehingga peserta didik tidak belum mampu menyelesaikan berbagai tagihan dalam pembelajaran. Oleh karena itu penulis terinspirasi untuk menerapkan salah satu komponen penunjang pembelajaran yang belum umum diterapkan oleh sekolah tersebut untuk meningkatkan hasil 
belajar peserta didik. Salah satu upaya untuk mencapai hal tersebut ialah dengan pemberian media pembelajaran yang menarik (Ntobuo et al., 2018), karena media pembelajaran menjadi bagian yang tak terpisahkan dalam proses pembelajaran (Pratiwi et al., 2019). Dalam penelitian ini peneliti memanfaatkan media komik sebagai sumber belajar.

Media komik merupakan bentuk komunikasi visual yang mudah untuk dipahami dan menarik perhatian karena sifatnya yang terdiri dari serangkaian gambar, membentuk alur cerita, dan memuat narasi yang padat serta jelas (Negrete, 2013; Rahmi \& Rahmati, 2020; Rokhayani \& Utari, 2014; Siregar et al., 2017). Karena sifatnya tersebut, penyampaian informasi yang disampaikan melalui komik cenderung dapat lebih mudah ditangkap dan diingat dalam jangka waktu lama. Hal ini didukung oleh penelitian yang dilakukan oleh Kurniawati et al. (2018) yang menjelaskan bahwa science comic berpengaruh terhadap hasil belajar siswa kelas VIII pada materi sistem peredaran darah manusia di SMP Negeri 7 Jember. Sejalan dengan penelitian yang dilakukan oleh Noning pada tahun 2018, berdasarkan hasil penelitian tersebut, dapat disimpulkan bahwa pembelajaran dengan media komik berpengaruh terhadap hasil belajar siswa pada submateri Pencemaran Lingkungan di kelas VII SMP Negeri 1 Air Besar. Dan pada penelitian yang dilakukan oleh Danaswari et al. (2013) disimpulkan bahwa terdapat perbedaan hasil belajar siswa yang signifikan antara kelas eksperimen dan kelas kontrol di kelas X SMAN 9 Cirebon pada pokok bahasan Ekosistem.

Melihat dari kondisi sekolah yang belum didukung oleh fasilitas teknologi yang dapat dijangkau dengan praktis, media komik menjadi salah satu alternatif media untuk belajar dengan cara yang menyenangkan dan dapat dijangkau dimanapun dan kapanpun peserta didik berada. Dengan karakteristik komik inilah, penulis terinspirasi untuk memadukan materi pembelajaran dengan komik, dengan harapan peserta didik dapat lebih termotivasi untuk mempelajari materi Virus dan dapat meningkatkan hasil belajar pada materi Virus.

\section{METODE}

Metode penelitian yang digunakan dalam penelitian ini metode true experiment, karena pada eksperimen ini terdapat dua kelas yang akan dijadikan sebagai subjek penelitian, yaitu kelas eksperimen (kelas dengan perlakuan media pembelajaran komik) dan kelas kontrol (kelas tanpa perlakuan media pembelajaran komik. Selain itu, pengambilan sampel dilakukan secara acak dari populasi yang ada.

1. Populasi dan Sampel

Populasi dalam penelitian ini adalah seluruh kelas X MIA MAN Kabupaten Tasikmalaya tahun ajaran 2019/2020 sebanyak 7 kelas dengan jumlah peserta didik sebanyak 240 orang. Populasi dianggap homogen, dilihat dari nilai rata-rata ulangan harian mata pelajaran biologi tahun ajaran 2019/2020, seperti yang ditunjukkan oleh Tabel 1 berikut. 
Tabel 1. Nilai Rata-Rata Ulangan Harian Peserta Didik Kelas X MIA MAN Kabupaten Tasikmalaya

\begin{tabular}{|c|c|c|c|}
\hline No. & Kelas & $\begin{array}{c}\text { Jumlah } \\
\text { Siswa }\end{array}$ & $\begin{array}{l}\text { Nilai Rata-Rata } \\
\text { Ulangan Harian }\end{array}$ \\
\hline 1. & X MIA 1 & 25 & 69,8 \\
\hline 2. & X MIA 2 & 36 & 63,4 \\
\hline 3. & X MIA 3 & 36 & 66,8 \\
\hline 4. & X MIA 4 & 35 & 69,6 \\
\hline 5. & X MIA 5 & 36 & 65,8 \\
\hline 6. & X MIA 6 & 36 & 63,2 \\
\hline \multirow[t]{3}{*}{7.} & X MIA 7 & 36 & 63,3 \\
\hline & Jumlah & 240 & 461,9 \\
\hline & Nilai Rata-Rata & & 66,0 \\
\hline
\end{tabular}

Sampel dipilih dengan menggunakan teknik cluster random sampling. Dengan demikian, kelas yang terpilih sebagai sampel adalah kelas X MIA 5 sebagai kelas eksperimen, dan kelas X MIA 7 sebagai kelas kontrol. Dimana masing-masing tiap kelasnya berjumlah 36 siswa.

2. Desain Penelitian

Desain penelitian yang digunakan dalam penelitian ini adalah posttest only control design. Menurut Creswell, John (2017:232) menyatakan bahwa:

\begin{tabular}{|lll|}
\hline $\mathrm{R}$ & $\mathrm{X}$ & $\mathrm{O} 1$ \\
$\mathrm{R}$ & & $\mathrm{O} 2$ \\
\hline
\end{tabular}

Keterangan:

Kelompok A : Kelas eksperimen

Kelompok B : Kelas kontrol

$\mathrm{R} \quad$ : Randomisasi

$\mathrm{X} \quad$ : Perlakuan

O1 : Posttest pada kelas eksperimen

O2 : Posttest pada kelas kontrol

\section{Teknik Pengumpulan Data}

Teknik pengumpulan data pada penelitian ini menggunakan teknik tes dan non-tes yang dilakukan setelah proses pembelajaran selesai (posttest), dalam bentuk angket sebanyak 22 pernyataan dan tes soal pilihan majemuk sebanyak 35 butir soal pada materi virus.

\section{Teknik Pengolahan dan Analisis Data}

Teknik pengolahan dan analisis data dalam penelitian ini yaitu dengan uji persyaratan analisis data menggunakan Uji Normalitas dengan Uji Kolmogorov-Smirnov dan Uji homogenitas dengan Levene's test, kemudian dilanjutkan dengan uji hipotesis menggunakan uji U Mann Whitney.

\section{Instrumen Penelitian}

Instrumen yang digunakan dalam penelitian ini adalah tes pilihan majemuk sebagai instrumen untuk mengukur hasil belajar dan angket untuk mengukur motivasi belajar peserta 
didik. Tes soal pilihan majemuk dibatasi pada ranah kognitif dari $\mathrm{C} 1-\mathrm{C} 5$, dan ranah pengetahuan dari K1-K3 yang terdiri dari 35 butir soal pada materi virus, sebagaimana yang terdapat pada Tabel 2. Sedangkan angket motivasi belajar sebanyak 30 butir pernyataan dari 6 indikator motivasi berdasarkan Uno (2017), sebagaimana yang ditampilkan pada Tabel 3. Berikut kisi-kisi instrument hasil belajar (Tabel 2) dan motivasi (Tabel 3) yang digunakan dalam penelitian ini.

Tabel 2. Kisi-Kisi Instrumen yang akan digunakan untuk mengukur Hasil Belajar pada Materi Virus di MAN 2 Kabupaten Tasikmalaya

\begin{tabular}{|c|c|c|c|c|c|c|c|c|}
\hline \multirow{2}{*}{ No } & \multirow{2}{*}{ Materi } & \multirow{2}{*}{$\mathbf{K}$} & \multicolumn{5}{|c|}{ Aspek Proses Kognitif yang Diukur } & \multirow[t]{2}{*}{ Jumlah } \\
\hline & & & C1 & $\mathrm{C} 2$ & $\mathrm{C} 3$ & $\mathrm{C} 4$ & $\mathbf{C 5}$ & \\
\hline \multirow[t]{3}{*}{1.} & Ciri-Ciri Virus & K1 & 1,7 & & 22 & 8 & & \multirow[t]{3}{*}{11} \\
\hline & & $\mathrm{K} 2$ & $2^{*}, 3^{*}$ & 6 & & $\begin{array}{l}5^{*} \\
10^{*}\end{array}$ & $11^{*}$ & \\
\hline & & K3 & & 9 & & & & \\
\hline \multirow[t]{3}{*}{2.} & Struktur Virus & K1 & $\begin{array}{ll}26, & 13, \\
14^{*} & \end{array}$ & & & 29 & & \multirow[t]{3}{*}{13} \\
\hline & & $\mathrm{K} 2$ & & $\begin{array}{l}16, \quad 37, \\
46^{*}\end{array}$ & 18,20 & 23 & 24 & \\
\hline & & K3 & & & & $4^{*}$ & 19 & \\
\hline \multirow[t]{3}{*}{3.} & Reproduksi Virus & K1 & 32,35 & 47 & $\begin{array}{l}25,12^{*}, 28 \\
31^{*}\end{array}$ & & & \multirow[t]{3}{*}{15} \\
\hline & & $\mathrm{K} 2$ & & & & 36 & & \\
\hline & & K3 & & & $21^{*}, 33$ & $\begin{array}{l}27^{*} \\
34\end{array}$ & $\begin{array}{l}17 * \\
38,39\end{array}$ & \\
\hline \multirow[t]{4}{*}{4.} & Peranan Virus dalam & $\mathrm{K} 1$ & 40 & & & & & \multirow[t]{3}{*}{11} \\
\hline & Kehidupan & $\mathrm{K} 2$ & & $\begin{array}{l}42^{*}, \quad 44, \\
45\end{array}$ & 41 & 15 & & \\
\hline & & K3 & & $43^{*}$ & & & $\begin{array}{l}30 *, \\
48,49, \\
50 .\end{array}$ & \\
\hline & Total & & 10 & 10 & 10 & 10 & 10 & 50 \\
\hline
\end{tabular}

Berdasarkan tabel 2 dari 50 butir soal, penulis menggunakan 35 butir soal sebagai instrumen penelitian soal hasil belajar, sedangkan jumlah soal yang tidak digunakan sebagai instrumen adalah sebanyak 15 butir karena tidak memenuhi kriteria validitas, yaitu soal nomor 2 , $3,4,5,10,12,14,17,21,27,30,31,42,43$, dan 46.

Tabel 3. Kisi-Kisi Instrumen yang akan digunakan untuk mengukur Motivasi Belajar pada Materi Virus di MAN 2 Kabupaten Tasikmalaya

\begin{tabular}{|c|c|c|c|c|}
\hline \multirow{2}{*}{ Aspek } & \multirow{2}{*}{ Indikator } & \multicolumn{2}{|c|}{ No. Item } & \multirow[t]{2}{*}{ Jumlah } \\
\hline & & + & - & \\
\hline \multirow{3}{*}{$\begin{array}{l}\text { Dorongan } \\
\text { internal }\end{array}$} & 1. Adanya hasrat dan keinginan untuk berhasil & $1,3,4^{*}$ & 2,5 & 4 \\
\hline & $\begin{array}{l}\text { 2. Adanya dorongan dan kebutuhan dalam } \\
\text { belajar }\end{array}$ & $6,8,9$ & $7,10,11$ & 6 \\
\hline & 3. Adanya harapan dan cita-cita & $12 *, 14,17$ & $13,15^{*}, 16$ & 4 \\
\hline \multirow[t]{3}{*}{$\begin{array}{l}\text { Dorongan } \\
\text { eksternal }\end{array}$} & 1. Adanya penghargaan dalam belajar & $20^{*}, 21,22^{*}$ & $\begin{array}{c}18^{*}, 19^{*} \\
23\end{array}$ & 2 \\
\hline & 2. Adanya kegiatan yang menarik dalam belajar & $24^{*}, 26,28^{*}$ & $\begin{array}{c}25^{*}, 27 \\
29^{*}\end{array}$ & 2 \\
\hline & $\begin{array}{l}\text { 3. Adanya lingkungan belajar yang kondusif } \\
\text { sehingga memungkinkan peserta didik dapat } \\
\text { belajar dengan baik }\end{array}$ & $30,32^{*}, 34$ & $31,33,35^{*}$ & 4 \\
\hline
\end{tabular}


Keterangan $\left(^{*}\right)$ : pernyataan tidak dipakai

Penskoran:

a) Untuk pernyataan positif: Sangat Setuju $(S S)=5$, Setuju $(S)=4$, Ragu-Ragu $(R R)=3$, Tidak Setuju (TS) $=2$, Sangat Tidak Setuju (STS) $=1$

b) Untuk pernyataan negatif: Sangat Setuju $(S S)=1$, Setuju $(S)=2$, Ragu-Ragu $(R R)=3$, Tidak Setuju (TS) $=4$, Sangat Tidak Setuju $($ STS $)=5$

Berdasarkan pada Tabel 3, dari 35 butir pernyataan, penulis menggunakan 22 butir pernyataan sebagai instrumen penelitian motivasi belajar, sedangkan jumlah soal yang tidak digunakan sebagai instrumen adalah sebanyak 13 butir karena tidak memenuhi kriteria validitas, yaitu soal nomor $4,12,15,18,19,20,22,24,25,28,29,32$, dan 35 .

\section{HASIL DAN PEMBAHASAN}

\section{Hasil}

1. Data Hasil Penelitian

Data yang diperoleh dari penelitian ini meliputi data posttest dari motivasi belajar (Tabel 1) dan hasil belajar (Tabel 2) peserta didik pada materi virus di kelas X MIA MAN Kabupaten Tasikmalaya.

Tabel 4. Statistik hasil posttest motivasi belajar peserta didik kelas eksperimen dan kelas kontrol

\begin{tabular}{lcc}
\hline & \multicolumn{2}{c}{ Posttest Motivasi Belajar } \\
\cline { 2 - 3 } & Kelas Eksperimen & Kelas Kontrol \\
\hline Rata-rata & 75,67 & 72,33 \\
Standar Deviasi & 8,078 & 7,294 \\
Varians & 65,257 & 53,200 \\
Minimum & 59 & 64 \\
Maksimum & 94 & 89 \\
\hline
\end{tabular}

Pada tabel 4 menunjukkan data hasil statistik motivasi belajar di kelas eksperimen dengan skor rata-rata posttest 75,67 , standar deviasi posttest 5,581 , varians posttest 65,257 , skor minimum 59 dan skor maksimum 94 . Sedangkan data hasil statistik motivasi belajar pada kelas kontrol, skor rata-rata posttest 72,33, standar deviasi posttest 7,293, varians posttest 53,200, skor minimum 64 dan skor maksimum 89.

Tabel 5. Statistik posttest hasil belajar peserta didik kelas eksperimen dan kelas kontrol

\begin{tabular}{lcc}
\hline & \multicolumn{2}{c}{ Posttest Hasil Belajar } \\
\cline { 2 - 3 } & Kelas Eksperimen & Kelas Kontrol \\
\hline Rata-rata & 67,56 & 61,44 \\
Standar Deviasi & 10,563 & 6,443 \\
Varians & 111,568 & 41,511 \\
Minimum & 43 & 46 \\
Maksimum & 86 & 69 \\
\hline
\end{tabular}

Pada tabel 5 menunjukkan data hasil statistik hasil belajar kelas eksperimen dengan skor rata-rata posttest 67,56 , standar deviasi posttest 10,563 , varians posttest 111,568 , skor minimum 43 
dan skor maksimum 86. Sedangkan pada kelas kontrol, menunjukkan data hasil statistik hasil belajar dengan skor rata-rata posttest 61,44 , standar deviasi posttest 6,443 , varians posttest 41,511, skor minimum 46 dan skor maksimum 69.

\section{Pengujian hipotesis}

Ringkasan pengujian hipotesis disajikan pada Tabel 3 berikut. Hasil pengujian hipotesis menyimpulkan bahwa "ada pengaruh media komik terhadap motivasi dan hasil belajar peserta didik pada materi virus di kelas X MAN Kabupaten Tasikmalaya tahun ajaran 2019/2020.

Tabel 6. Ringkasan Hasil Uji Hipotesis U Mann Whitney

\begin{tabular}{lcc}
\hline & Motivasi Belajar & Hasil Belajar \\
\hline U U Mann Whitney U & 461,000 & 413,500 \\
Wilcoxon W & 1127,000 & 1079,500 \\
Z & $-2,109$ & -2.658 \\
Asymp. Sig. (2-tailed) & 0,035 & 0,008 \\
\hline
\end{tabular}

Pada tabel 6, menunjukkan ringkasan hasil pengujian hipotesis menggunakan uji U Mann Whitney. Nilai signifikasi pada motivasi belajar sebesar 0,035 sedangkan pada hasil belajar adalah 0,008. Karena nilai signifikansi pada keduanya di bawah 0,05 maka diasumsikan terdapat pengaruh media komik terhadap motivasi dan hasil belajar. Sehingga pada tingkat kepercayaan 95\% dapat disimpulkan bahwa terdapat perbedaan motivasi dan hasil belajar yang signifikan pada peserta didik antara yang mendapatkan perlakuan dengan media komik dan dengan yang tidak.

\section{Pembahasan}

Berdasarkan hasil penelitian yang dilakukan dan setelah diuji dengan menggunakan uji U Mann Whitney untuk mengetahui pengaruh media komik terhadap motivasi dan hasil belajar peserta didik secara simultan dapat dilihat dari angka signifikasi pada bagian Asymp. Sig. (2tailed). Nilai signifikasi pada motivasi belajar sebesar 0,035 sedangkan pada hasil belajar adalah 0,008. Karena nilai signifikansi pada keduanya di bawah 0,05 maka Ha diterima. Sehingga pada tingkat kepercayaan 95\% dapat disimpulkan bahwa terdapat pengaruh yang signifikan antara peserta didik yang menggunakan media komik dengan peserta didik yang menggunakan konvensional, sebagai kontrol. Adanya perbedaan perlakuan antara kelas eksperimen dan kelas kontrol mempengaruhi peserta didik dalam proses pembelajaran sehingga terdapat perbedaan hasil posttest di antara kedua kelas tersebut.

Adanya pengaruh tersebut karena sifat komik yang terdiri dari banyak gambar yang disusun menjadi alur cerita, peserta didik merasa tertarik untuk membaca dengan seksama (Negrete, 2013). Selain itu, karena dipadukan dengan model Discovery Learning, membuat peserta didik aktif saling berdiskusi mengenai isi materi yang disusun menjadi komik tersebut dan bertanya apabila ada hal yang kurang dimengerti baginya. Respon tersebut sejalan dengan pernyataan 
Sudjana dan Rivai (2013) dalam Budiarti (2016), bahwa, "Peranan pokok dari media komik dalam pengajaran adalah kemampuannya dalam menimbulkan motivasi belajar para siswa, penggunaan media komik dalam pembelajaran yang dipadu dengan metode mengajar dapat menjadi alat pengajaran yang efektif yang diharapkan dapat berfungsi sebagai jembatan untuk menumbuhkan motivasi belajar baca peserta didik."

Media komik memiliki kelebihan diantaranya mengandung banyak gambar dan mengandung bahasa yang sederhana dan cenderung mudah diserap, sehingga menarik perhatian peserta didik dan memudahkan peserta didik untuk memahami suatu peristiwa yang terkandung di dalamnya. Hal ini diperkuat oleh hasil penelitian Ntobuo et al., (2018), bahwa materi yang disajikan melalui komik dengan dukungan materi yang sederhana, konten budaya yang menarik, dan mengangkat tradisi local akan menjadi lebih menarik perhatian peserta didik. Hal ini juga sejalan dengan pernyataan Trimo dalam Kustianingsari dan Dewi (2015), "Materi yang terdapat di dalam komik dapat menjelaskan keseluruhan cerita karena terdapat ilustrasi gambar yang dapat mempermudah siswa mengetahui bentuk atau contoh kongkrit mengenai maksud dari suatu materi." Dan Qurotu (tanpa tahun) dalam Noning (2018), yang menyatakan bahwa "Pembelajaran dengan menggunakan komik dapat menarik semangat peserta didik untuk membaca materi dalam bentuk cerita dan gambar."

Selain mendorong peserta didik untuk belajar, adanya alur cerita yang terkandung di dalamnya membantu peserta didik untuk meningkatkan kemampuannya dalam mengingat. Karena dalam proses menerima materi tersebut dilakukan dengan cara yang menyenangkan, yaitu dengan bebas berimajinasi, namun tetap diarahkan untuk mempelajari materi yang terkandung dalam komik tersebut. Seperti yang dikemukakan oleh Bowkett dan Hitchman (2012:1-2) dalam Budiarti dan Haryanto (2016:37-38), bahwa "Dalam sebuah gambar terdapat banyak arti dan informasi, dapat merangsang pembaca untuk lebih menggali sisi intelektualnya dengan cara yang mudah karena bacaan komik adalah bacaan yang menarik. Komik dianggap dapat meningkatkan daya ingat karena berurutan, menggunakan daya ingat dan imajinasi sendiri."

Media komik dapat digunakan untuk meningkatkan motivasi dan hasil belajar peserta didik pada materi virus. Media komik merupakan salah satu media yang tepat untuk digunakan dalam mata pelajaran yang membutuhkan penjabaran yang baik secara visualisasi dan mengandung banyak teori yang harus dihafal seperti materi biologi yang sebagian besar bersifat abstrak. Karena sifat komik yang cenderung mudah diingat karena pembawaannya yang menarik, usaha untuk mengingat dan memahami materi akan menjadi lebih mudah dibandingkan dengan buku paket. Hal ini sejalan dengan pernyataan Bowkett dan Hitchman (2012:1-2) dalam Budiarti dan Haryanto (2016:37-38), bahwa "Komik menggabungkan daya tarik cerita dan unsur-unsur narasi yang dapat diterima dengan mudah oleh sebagian besar anak, bahkan oleh anak-anak yang memiliki kesulitan membaca dan menulis." 
Hasil belajar yang tinggi dapat diperoleh melalui kemampuan siswa dalam mengingat dan memahami materi pembelajaran yang diberikan selama proses pembelajaran. Dengan menggunakan media komik, peserta didik dapat lebih mudah mengingat dan memahami materi yang dipelajari. Hal ini sejalan dengan Suwantini, (2015), bahwa "Media visual dapat mempermudah siswa untuk memahami konsep dari materi yang sedang diajarkan serta mengingat kembali materi yang disampaikan oleh guru."

Pernyataan tersebut dapat didukung secara deskriptif melalui perolehan skor rata-rata posttest. Peserta didik pada kelas eksperimen yang proses pembelajarannya menggunakan media komik memperoleh nilai rata-rata motivasi belajar sebesar 75,67 dan hasil belajar sebesar 67,56. Sementara peserta didik pada kelas kontrol yang proses pembelajarannya dengan media LKS dan buku paket memperoleh nilai rata-rata posttest motivasi belajar sebesar 72,33 dan hasil belajar sebesar 61,44. Berikut diagram skor rata-rata posttest motivasi dan hasil belajar pada setiap indikator pada kelas eksperimen dan kelas kontrol.

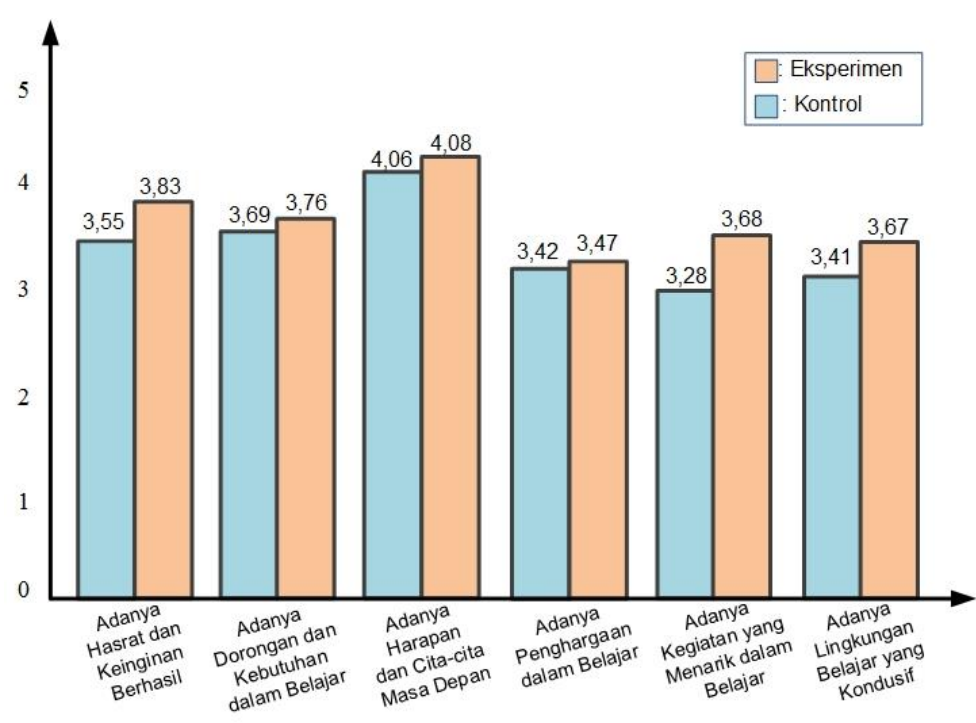

Gambar 1. Diagram Rata-Rata Skor Motivasi Belajar dalam Setiap Indikator di Kelas Eksperimen dengan menggunakan Media Komik

Gambar 1 menunjukkan bahwa skor tertinggi motivasi belajar yang dicapai di kelas eksperimen terdapat pada indikator motivasi ketiga, yakni adanya harapan dan cita-cita masa depan dengan rata-rata skor 4,08. Hal ini menunjukkan bahwa peserta didik termotivasi untuk belajar dikarenakan memiliki harapan dan cita-cita masa depan yang tinggi. Sementara itu, skor terendah motivasi belajar peserta didik terletak pada indikator adanya penghargaan dalam belajar, yakni sebesar 3,47 poin. Hal ini menunjukkan bahwa peserta didik mengharapkan nilai bagus dari guru, namun hal tersebut tidak menjadi alasan utama peserta didik untuk mengikuti proses pembelajaran. Disamping kedua indikator tersebut, keempat sisa indikator lainnya juga memiliki perolehan rata-rata skor yang cukup tinggi, yaitu adanya hasrat dan keinginan untuk berhasil sebesar 3.83 poin, adanya dorongan dan kebutuhan dalam belajar sebesar 3,76 poin, adanya 
kegiatan yang menarik dalam belajar sebesar 3,68 poin dan adanya lingkungan belajar yang kondusif sehingga memungkinkan peserta didik dapat belajar dengan baik sebesar 3,67 poin. Hal ini menjelaskan bahwa keinginan peserta didik untuk berhasil, dorongan dan kebutuhan peserta didik untuk belajar, adanya kegiatan yang menarik dalam belajar dan lingkungan belajar yang kondusif juga memiliki kontribusi yang cukup besar dalam memotivasi peserta didik untuk belajar. Walaupun tidak setinggi indikator harapan dan cita-cita masa depan peserta didik, dan tidak juga serendah adanya penghargaan dalam belajar. Sedangkan dalam kelas kontrol, skor tertinggi yang dicapai sama dengan kelas eksperimen, yakni indikator ketiga. Sementara skor posttest terendah motivasi belajar peserta didik terdapat pada indikator adanya kegiatan yang menarik dalam belajar, yakni sebesar 3,28 poin. Sedangkan pada indikator adanya kegiatan yang menarik dalam belajar, presentasenya lebih rendah dikarenakan pembelajaran berlangsung sama seperti biasanya, tidak terdapat hal atau kegiatan baru untuk dilakukan.

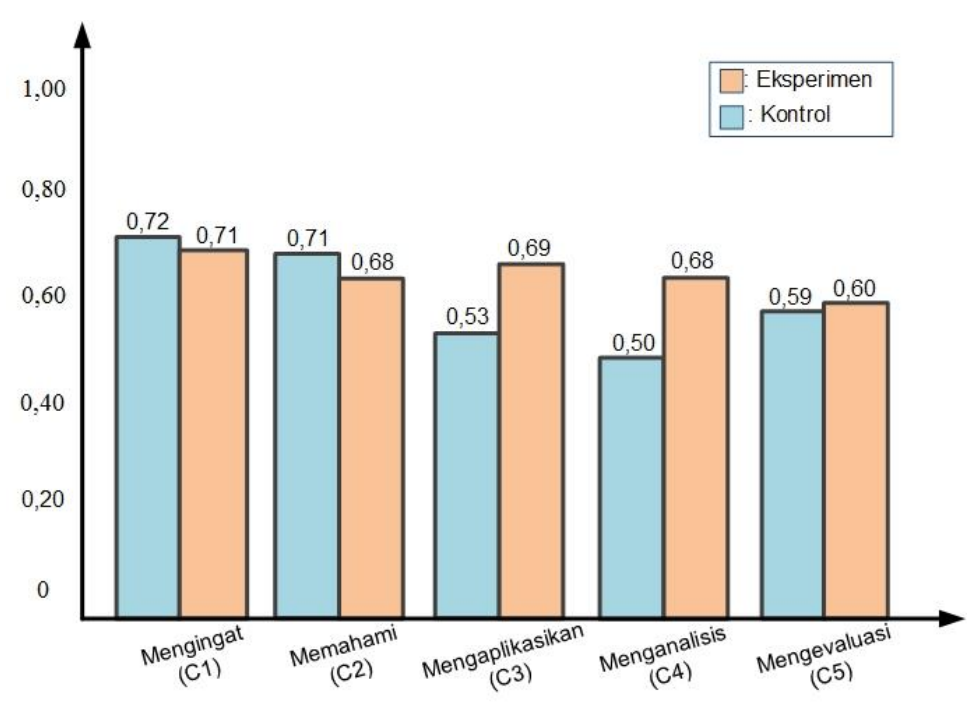

Gambar 2. Diagram Rata-Rata Skor Hasil Belajar dalam Setiap Indikator di Kelas Eksperimen dengan menggunakan Media Komik

Gambar 2 menunjukkan bahwa ketercapaian tingkatan kognitif dengan hasil yang paling tinggi pada kelas eksperimen terdapat pada kategori mengingat (C1) yaitu sebesar 0,71 . Hal ini menunjukkan bahwa melalui media komik, kemampuan mengingat (C1) peserta didik baik. Kemampuan kognitif peserta didik dalam kategori mengingat merupakan kemampuan yang paling dikuasai oleh peserta didik. Kategori C1 merupakan kategori paling dasar dalam tingkatan dimensi kognitif. Dalam kategori $\mathrm{C}$, peserta didik dituntut untuk memiliki kemampuan dalam mengenali dan mengingat kembali informasi yang telah tersimpan dalam memori jangka panjang. Hal ini cukup mendasar karena tidak membutuhkan proses berpikir yang bersifat komplikatif, sehingga peserta didik tidak terlalu merasa kesulitan dalam menjawab soal berkategori mengingat (C1) karena sifatnya yang me-recall (mengingat kembali) ingatan peserta didik. Hal ini sejalan 
dengan ungkapan Efendi, (tanpa tahun), bahwa kategori C1 (mengingat) adalah mengambil pengetahuan yang relevan dari memori jangka panjang, yang merupakan proses kognitif dengan tingkatan paling rendah. Sementara itu, ketercapaian tingkatan kognitif dengan hasil yang paling rendah adalah terdapat pada kategori mengevaluasi (C5), yakni sebesar 0,60. Hal ini menunjukkan bahwa media komik kurang mampu meningkatkan kemampuan kognitif mengevaluasi (C5) peserta didik bila dibandingkan dengan indikator lainnya dalam proses kognitif. Hal ini dapat dikarenakan kategori C5 adalah tingkatan kognitif tertinggi yang diukur dalam penelitian ini, kategori C5 ini menuntut peserta didik untuk membuat suatu pertimbangan atau penilaian berdasarkan kiteria dan standar yang ada (Efendi, t.t). Diantaranya meliputi kemampuan dalam memeriksa dan mengkritisi. Kategori ini tergolong cukup sulit untuk dikuasai karena diperlukan pengetahuan kognitif $\mathrm{C} 1-\mathrm{C} 4$ yang tinggi sebagai dasar pertimbangan tersebut. Tidak hanya demikian, kemampuan mengkritisi yang dimiliki oleh peserta didik secara individu juga menjadi faktor keberhasilan dalam pencapaian kategori ini. Sedangkan pada kelas kontrol, ketercapaian tingkatan kognitif dengan hasil yang paling tinggi sama dengan kelas eksperimen, yakni terdapat pada kategori mengingat (C1), yakni sebesar 0,72. Sedangkan tingkatan kognitif terendah terdapat dalam kategori menganalisis (C4) yaitu sebesar 0,50. Rendahnya hasil belajar pada kategori $\mathrm{C} 4$, menunjukkan bahwa kemampuan berpikir tingkat tinggi pada peserta didik yang menggunakan media LKS dan buku paket terkhusus dalam kemampuan menganalisis belum cukup baik bila dibandingkan dengan kategori lainnya.

Pada kelas kontrol yang menggunakan media LKS dan buku paket, peserta didik memiliki batasan dalam mengumpulkan informasi. Hal ini dapat dikarenakan media LKS dan buku paket yang digunakan oleh mayoritas peserta didik belum mengandung materi yang terperinci dan kurang mengandung gambar yang mampu memvisualisasikan maksud dari isi materi yang disajikan. Selain itu, secara visual penyajian media LKS dan buku paket cenderung monoton dan kurang menarik, berkebalikan dengan media komik yang penuh gambar dan warna yang berwarna-warni. Hal tersebut bertentangan dengan ungkapan Sudjana dan Rivai (2011:26) dalam Surwantini (2015), bahwa "Hal-hal yang harus diperhatikan agar suatu media visual dapat efektif digunakan untuk meningkatkan motivasi belajar yaitu dengan memperhatikan beberapa hal, seperti kesederhanaan, keterpaduan, komposisi, penekanan, keseimbangan, ruang, tekstur, serta warna." 


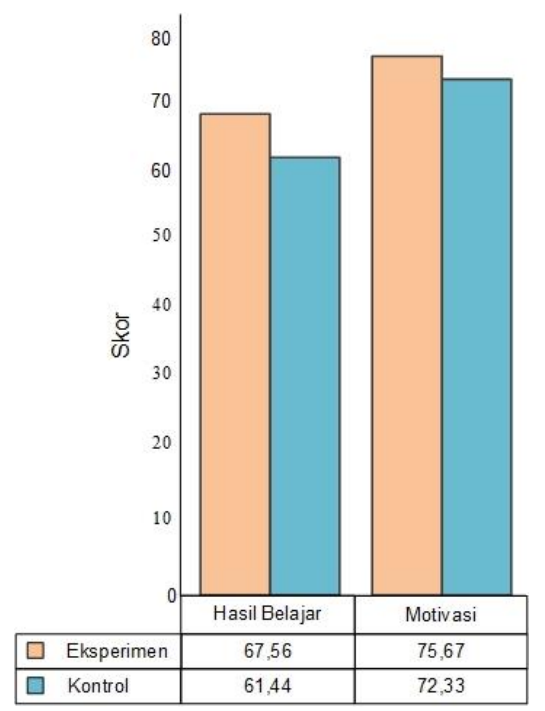

Gambar 3. Diagram skor rata-rata posttest motivasi dan hasil belajar peserta didik di kelas eksperimen dan kelas kontrol.

Atas dasar perbedaan tersebut, diduga menjadi salah satu penyebab peserta didik kurang terdorong untuk membaca dan mempelajari materi yang terdapat di dalamnya. Walaupun peserta didik memiliki rasa keingintahuan yang tinggi terhadap materi virus, hal tersebut tidak berimbang dengan dorongan untuk membaca literatur untuk mengumpulkan informasi-informasi yang dibutuhkan. Di sisi lain, bila peserta didik terdorong untuk membaca sumber belajar, peserta didik akan melakukannya dengan perasaan keterpaksaan. Hal tersebut mengakibatkan ilmu yang diperoleh dari sumber pelajaran tersebut tidak bertahan lama dalam ingatan karena proses belajar tidak dirasa menyenangkan. Sehingga, mengakibatkan hasil belajarnya lebih rendah dari kelas eksperimen yang menggunakan media komik sebagai sumber belajar. Hal ini sejalan dengan pernyataan Indrayanti dana Jailani (2015:87) dalam Budiarti dan Haryanto (2016) bahwa "Materi pembelajaran yang dikemas dalam alur cerita yang jelas akan membuat materi tersebut bertahan lebih lama dalam ingatan siswa."

\section{SIMPULAN}

Berdasarkan hasil penelitian, pengolahan data, dan pengujian hipotesis maka diperoleh simpulan bahwa media komik berpengaruh terhadap motivasi dan hasil belajar peserta didik pada materi virus di kelas X MIA MAN Kabupaten Tasikmalaya Tahun Ajaran 2019/2020. Pembelajaran dengan media komik memiliki dampak positif terhadap motivasi belajar peserta didik, dan mampu meningkatkan hasil belajar peserta didik pada kemampuan kognitif mengaplikasikan (C3), menganalisis (C4), dan mengevaluasi (C5).

Berdasarkan simpulan dari hasil penelitian yang telah dilakukan, penulis mengajukan dan mengusulkan beberapa saran sebagai berikut: 
1. Dalam penerapan media pembelajaran komik, guru hendaknya mengelola waktu dengan baik dalam pelaksanaan pembelajaran. Sehingga media komik dapat digunakan oleh peserta didik seefektif mungkin.

2. Guru hendaknya menggunakan media komik pada materi-materi biologi yang sesuai dengan karakteristik media tersebut, sehingga materi pembelajaran dapat tersampaikan secara maksimal dan dapat meningkatkan motivasi serta hasil belajar peserta didik.

3. Bagi peneliti selanjutnya, hendaknya menggunakan media komik pada materi-materi biologi yang tidak terlalu banyak mengandung istilah dan tidak mengandung materi yang bersifat kompleks (contoh: materi anatomi tubuh manusia, dll). Karena hal tersebut dapat berpotensi membingungkan peserta didik, terutama pada peserta didik yang tidak terbiasa dengan media komik. Selain itu, hal tersebut juga dapat menyebabkan pembahasan akan menjadi terlalu lebar, dan mengakibatkan waktu akan terbuang terlalu lama bagi peserta didik dalam mengumpulkan informasi.

4. Bagi peneliti selanjutnya, hendaknya mempersiapkan media komik dari jauh-jauh hari, menyesuaikan dengan kecepatan peneliti selanjutnya dalam proses penyusunan komik. Karena dalam pembuatan media komik diperlukan banyak waktu dalam mempertimbangkan penyusunan dan pematangan isi materi.

\section{REFERENSI}

Budiarti, Wahyu Nuning dan Haryanto. (2016). Pengembangan Media Komik untuk Meningkatkan Motivasi Belajar dan Keterampilan Membaca Pemahaman Siswa Kelas IV. [Online]. Tersedia: https://journal. uny.ac.id/index.php/jpe/article/view/6295. Diakses: 8 Maret 2020.

Danaswari, R. W., Kartini., E. Roviati (2013). Pengembangan Bahan Ajar dalam Bentuk Media Komik untuk Meningkatkan Hasil Belajar Siswa Kelas X SMAN 9 Cirebon pada Pokok Bahasan Ekosistem. Jurnal Scientiae Educatie, 2. Sumber: http://syekhnurjati.ac.id/jurnal/index.php/sceducatia/article/view /477.

Effendi, Ramlan (tanpa tahun). Konsep Revisi Taksonomi Bloom dan Implementasinya pada Pelajaran Matematika SMP. [Online]. Tersedia: https://media.neliti.com/ media publications/90966-ID-konsep revisi-taksonomi-bloom-dan-implem.pdf.

Kurniawati, Desi et.al. (2018). Pengaruh Science Comic Terhadap Hasil Belajar Siswa. [Onine]. Tersedia: http://jurnal.unpad.ac.id/farmaka/article/view/ 12285. Diakses: 17 September 2019.

Kustianingsari, Nadia dan Utari Dewi (tanpa tahun). Pengembangan Media Komik Digital pada Mata Pelajaran Bahasa Indonesia Tema Lingkungan Sahabat Kita Materi Teks Cerita Manusia dan Lingkungan untuk Siswa Kelas V SDN Putat Jaya III/379 Surabaya. Sumber: http://jurnalmahasiswa. unesa.ac.id/index.php/jmtp/article/view/1307.

Noning (2018). Efektivitas Komik terhadap Hasil Belajar Siswa Materi Pencemaran Lingkungan SMP $\begin{array}{lllll}\text { Negeri } & 1 & \text { Air } & \text { Besar. } & \text { [Online]. }\end{array}$ http://jurnal.untan.ac.id/index.php/jpdpb/article/view/23803. Diakses: 8 Maret 2020.

Nurkholis, (2013). Pendidikan dalam Upaya Memajukan Teknologi. [Online]. Tersedia: http://ejournal.iainpurwo kerto.ac.id/index.php/jurnalkependidikan/article/view/530. 
Diakses: 2 Oktober 2019.

Negrete, A. (2013). Constructing a Comic to Communicate Scientific Information about Sustainable Development and Natural Resources in Mexico. 13th International Educational Technology Conference, 103, 200-209. https://doi.org/10.1016/j.sbspro.2013.10.327

Ntobuo, N. E., Arbie, A., \& Amali, L. N. (2018). The Development of Gravity Comic Learning Media Based on Gorontalo Culture. Jurnal Pendidikan IPA Indonesia, 7(2), 246-251. https://doi.org/10.15294/jpii.v7i2.14344

Pratiwi, R. H., Sulistyaniningsih, E., \& Septianzah, K. (2019). Aplikasi Chem Draw sebagai Media Inovasi Guru dalam Pengajaran IPA Terpadu. Bioedusiana, 4(2), 38--43. https://doi.org/https://doi.org/10.34289/285228

Rahmi, I., \& Rahmati. (2020). Application of Comic Media to Improve Learning Outcomes and Educational Affective Students on Straight Motion Material in Class VIII SMP Negeri 1 Darul Imarah Aceh Besar. Jurnal Phi, 1(2), 27-36.

Raida, Sulasfiana Alfi. (2018). Identifikasi Materi Biologi SMA Sulit Menurut Pandangan Siswa dan Guru SMA Se-Kota Salatiga. [Online]. Tersedia: http://journal.stainkudus.ac.id/index.php/jobe/article/view/418. Diakses: 1 September 2019.

Rokhayani, A., \& Utari, A. R. P. (2014). The Use of Comic Strips as an English Teaching Media for Junior High School Students. Language Circle - Journal of Language and Literature, 8(2), 143149. https://doi.org/10.15294/lc.v8i2.3018

Siregar, A. D., Rini, \& Herdini. (2017). The Application of Comic Learning Media to Improve Student's Achievement on Reduction and Oxidation Reaction Topic. Proceeding of the 2nd Annual International Seminar on Transformative Education and Educational Leadership, 2, 146149. http://aisteel2017.unimed.ac.id/wp-content/uploads/2018/03/146-149.pdf

Surwantini, Eti (2015). Efektivitas Penggunaan Media Visual terhadap Motivasi Belajar Dan Prestasi Belajar Siswa Kelas III SD Gugus 01 Imogiri, Bantul. [Online]. Tersedia: https://journal.uny.ac.id/index.php/jpip/article/view /8273. Diakses: 8 Maret 2020. 